\title{
Epidemiological and clinical aspects of the COVID-19 pandemic and world common experiences in treatment: Turkey experience
}

\section{COVID-19 pandemisinin epidemiyolojik ve klinik yönleri ve tedavide dünyanın ortak deneyimleri: Türkiye deneyimi}

\author{
Hasan KARAGEÇiLi'i ${ }^{1}$ Zuhal YILDIRIM²
}

\section{ABSTRACT}

The COVID-19 outbreak like SARS and MERS would have been thought to end in China. But it has not been envisaged, spread in Iran then Italy to continental Europe and spread to America in very prevalant and in a very short time. It was thought that looking to China from Turkey was very distant story for us. When it showed that the heavy influence on Italy, gave us the idea to be our next photograph. No matter how slow the World Health Organization behaved, the fact that it declared the disease as a pandemic during this period, increased the seriousness. COVID-19, after confirmation with the PCR test, the detection of spread in the lungs with radiological imaging chest tomography is also done. Commonly presented clinical findings were characterized by fever, cough, headache and muscle weakness. Some person recovered with mild symptoms of this disease contrary to the high level of contagiousness without symptoms of this disease sign both a good and a bad condition. It is very crucial to avoid contact, to protect personal distance, to wear a mask and to pay attention to hand hygiene to prevent disease transmission from human to human. It is important for those with suspected diseases to isolate themselves, to be quarantined and to be kept under the supervision of a doctor. The screening
\end{abstract}

\section{ÖZET}

COVID-19 salgınının SARS ve MERS gibi Çin'de sona ereceği düșünülüyordu. Ancak öngörülemedi, İran'a, sonra İtalya'dan Avrupa kıtasına yayıldı ve kısa sürede ve yaygın șekilde Amerika'ya yayıldı. Türkiye'den Çin'e bakmanın bizim için çok uzak bir hikaye olduğu düșünülüyordu. İtalya üzerindeki ağır etkisini gösterdiğinde, bir sonraki fotoğrafımız olduğu fikrini verdi. Dünya Sağlık Örgütü ne kadar yavaș davranırsa davransın, hastalığı bu dönemde salgın olarak ilan etmesi ciddiyeti arttırdı. COVID-19, PCR testi ile onaylandıktan sonra, radyolojik görüntüleme (göğüs tomografisi) ile akciğerlerdeki yayılma tespit edilmektedir. Genel klinik bulguları ateș, öksürük, baș ağrısı ve kas güçsüzlüğü ile karakterizedir. Bu hastalığı hafif atlatanların olmasının yanında, semptom göstermeden bulașıcılığının yüksek oranda olması hem iyi hem kötü, ikili bir durum doğurmaktadır. Hastalığın insandan insana bulașmasını önlemek için temastan kaçınmak, kișisel mesafeyi korumak, maske takmak ve el hijyenine dikkat etmek çok önemlidir. Şüpheli hastalığı olanların kendilerini izole etmeleri, karantinaya alınmaları ve bir doktor gözetiminde tutulmaları önemlidir. Son üç gün aileleri ile temas halinde olan hastaların taranması ve

'Siirt University, Faculty of Health Sciences, Siirt

${ }^{2}$ Ankara Health Directorate, Public Health Services Presidency, Ankara

İletişim / Corresponding Author : Zuhal YILDIRIM 
and observation of patients with whom they have been in contact with their families for the last three days is the best way to break the chain of contamination. Teams established to contact tracing are working hard in our country. The number of patient cases in Turkey as of May 22, 154.500. The number of death was 4.276, with $2.8 \%$ ratio. COVID-19 case numbers and mortality rates declined with the curfew of over 65-year old people and younger than 20s. With the drugs that were used in the treatment protocol as hydroxychloroquine, favipiravir and supportive treatments, in Turkey, it is stated that the treatment was good.

Anahtar Kelimeler: COVID-19, pandemic, contact tracing, epidemiology gözlemlenmesi, kontaminasyon zincirini kırmanın en iyi yoludur. Ülkemizde filyasyon için kurulan ekipler çok çalıșmaktadır. Hasta vaka sayısı Türkiye'de 22 Mayıs itibariyle 154.500 idi. Ölü sayısı 4276, mortalite oranı ise \%2.8 idi. COVID-19 vaka sayıları ve mortalite oranları, 65 yașın üzerindeki ve 20 yașından küçüklerin sokağa çıkmalarının kısıtlanması ile azaldı. Tedavi protokolünde kullanilan hidroksiklorokin, favipiravir ilaçları ve destekleyici tedaviler ile Türkiye'de tedavinin bașarılı olduğu belirtilmektedir.

Key Words: COVID-19, pandemi, filyasyon, epidemiyoloji

\section{INTRODUCTION}

In late December 2019, a group of patients were accepted to hospitals with a diagnosis of pneumonia of unrecognized etiology. These patients were epidemiologically related to a seafood and livestock wholesale market in Wuhan, the capital city of Hubei Province, China (1). Wuhan city became the center of an unknown pneumonia epidemic in December 2019. On January 7, 2020, Chinese scientists isolated a new coronavirus, severe acute respiratory syndrome coronavirus 2 (SARS-CoV-2; formerly studied 2019$\mathrm{nCoV})$ from these patients with virus-infected pneumonia (2). By the World Health Organization (WHO) this novel coronavirus-infected pneumonia was called as coronavirus disease 2019 (COVID-19) on the February 11, 2020 (3). Because the first epidemic data enormously conform to exponential progress, in the preliminary work the average approximation of reproduction number (RO) for the 2019-nCoV was found to extent from 2.24 to 3.58 , and that is remarkably larger than 1 .
These findings indicated the potential of 2019nCoV to result in epidemics (4). COVID-19 looks extremely infectious. It is primarily classified as a type of RNA virus belonging to the coronavirus family leading to respiratory system disease. One of the predominant marks for COVID-19 is pneumonia (5). When the number of newly confirmed cases in China increased 13 times, WHO decided to characterize COVID-19 as a pandemic on March 11, 2020 and asked member states to expand their emergency response mechanisms (6). COVID-19 is an pandemic with an estimated mortality between $1 \%$ and $5 \%$; and an estimated R0 of 2.2 to 6.7 , according to various sources (7). As of March 28, 2020, there were more than 649.000 confirmed cases and a total of 30.249 deaths worldwide (8). This virus is transmitted from person to person within $2 \mathrm{~m}$ of land on the surfaces of the person contaminated with large cough, sneezing or rhinorrhea droplets. The COVID-19 virus can survive for at least 24 hours on hard surfaces and up 
to 8 hours on soft surfaces. The virus is transmitted to another person by hand contact on a contaminated surface and then touching the mouth, nose or eyes. Aerosol airborne contaminated particles formed during sneezing or coughing can stay in the air for 3 hours (9). CoVs, the largest well-known RNA viruses, are also divided into four genera: alpha-coronavirus, beta-coronavirus, gamma-coronavirus, and deltacoronavirus (10). Six coronaviruses were formerly noted to bring about disease in humans, SARS-CoV-2 is the seventh member of the coronavirus family that infects human beings after SARS-CoV and MERS-CoV. SARS-CoV-2, such as SARS-CoV and MERS-CoV, belongs to $B$-coronavirus. The genome sequence homology of SARS-CoV-2 and SARS is about 79\%, the 2019 $\mathrm{nCoV}$ is closer to the SARS-like bat CoVs (MG772933) than the SARS-CoV (11). Verification of the disease is done using nucleic acid amplification tests (NAAT), such as real-time reverse transcriptase polymerized chain reaction (RT-PCR). Imaging of the lungs on chest computed tomography (CT) is important in the scope and follow-up of COVID-19 pneumonia $(12,13)$. Parametric research shows that the growth rate of COVID-19 is approximately twice that of SARS and MERS, and that the COVID-19 doubling cycle is between two and three days, which means that the number of COVID-19 patients would double within two to three days without human intervention (14). Results from a meta-analysis of 46.248 infected patients showed that the most common comorbidity was hypertension $(17 \pm 7.95 \% \mathrm{Cl} 14-22 \%)$ and diabetes $(8 \pm 6.95 \% \mathrm{Cl}$ 6-11\%), followed by cardiovascular diseases $(5 \pm 4.95 \%$ $\mathrm{Cl} 4-7 \%)$ and respiratory system disease $(2 \pm 0.95 \% \mathrm{Cl}$ $1-3 \%)(15)$. The average time from onset of symptoms to death is 17.8 days (95\% reliable interval [Crl] 16.9-19.2) and hospital discharge time is 24.7 days (22.9-28.1). Crude case mortality rate was (adjusted for censorship) 3.67\% (95\% Crl 3.56-3.80). However, after further adjustments under demography and determination, China achieved the best estimate of $1.38 \%(1.23-1.53)$ case death rate (16).

COVID-19 was widely seen in China in December and in February in many countries around the world. The first case was seen in Turkey on March 10. As the number of tests increased every day, the number of positive cases increased. As of May 22, the total number of tests performed was 1.767.495, the number of intensive care patients was 800 , the total number of intubated patients was 401 , the number of tests performed was 37.507 , the number of cases was 952 , the number of deaths was 27 , the number of recovered patients was 1.121 , the total number of cases was 154.500 , the total recovered patient number was 116.111 , the total number of deaths was 4.276 and the recovered patients rate was $75 \%$, mortality rate was $2.8 \%$, in Turkey. Figure 1 below shows the data of Turkey (17).

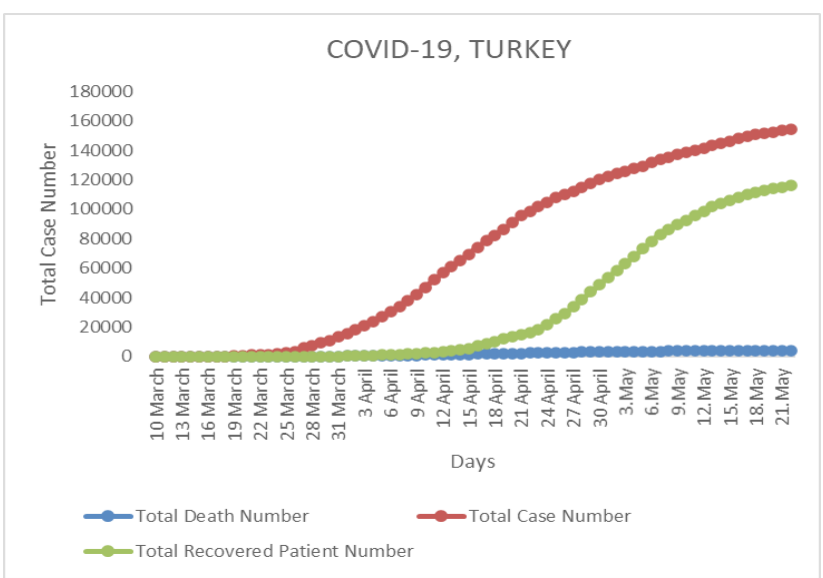

Figure 1. Turkey datas, total case number, total death number, total recovered patients number up to 22 May 2020 (17) 
The average total cases were 5.235.452, the total recovered patients were 2.072.768 and total death cases were 338.612 , the recovered rate was $39 \%$ and the death rate was $6.5 \%$ worldwide in May 22 . The most important issue that the health minister emphasized was to determine contact tracing. Ro number was 4.3 in mid-April in Turkey. A sick person infects an average of 4.3 people. As a result of prevention efforts, Ro number was calculated as 1.56 on May 13 and 0.72 on May 20. Contact tracing may vary depending on the socio-cultural situation of societies. With the 5.300 contact tracing team, each COVID-19 patient who has a positive diagnosis is determined to be in contact with whom up to three days ago. It was emphasized that the effectiveness of family physicians is another important point. They stated that favipiravir, which is one of the drugs in the treatment protocol, is used firstly in patients not need intensive care and that its therapeutic effect was good. In addition, one million boxes of hydroxychloroquine drugs using in treatment are in stocks. This situation leads us to the conclusion that the medications we use in the treatment protocol are effective. These drugs are hydroxychloroquine sulfate, which the Food and Drug Administration (FDA) give permission to be tested, and favipiravir, which we bought from China. It was announced by the health minister that favipiravir drug, which was sent for use in intensive care in almost all provinces, has been used in treatment since April 1. It was stated that it was beneficial in patient recover. And also an antibacterial, macrolid group drug, azithromycin is used against COVID-19.

\section{Genetics}

The genetic sequence of COVID-19 showed more than $80 \%$ identity to SARS-CoV and more than $50 \%$ to MERS-CoV. Both SARS-CoV and MERS-CoV were caused by bats (1). The virus genome consists of six main open reading frames (ORF) common to coronaviruses and a number of other helper genes. Further analysis shows that some of the 2019-nCoV genes shared less than $80 \%$ nucleotide sequence identity with SARS-CoV. However, the amino acid sequences of the seven conserved replicase domains used for the classification of $\mathrm{CoV}$ species in ORF1ab were 94.4\% identical between 2019-nCoV and SARS-CoV, indicating that the two viruses belong to the same species, SARSr-CoV (18). While $96.08 \%$ similarity was found between COVID-19 and SARS CoV Mpro, $51.61 \%$ low similarity was found for COVID-19 and MERS CoV Mpro. The number of COVID-19 amino acid differences for SARS-CoV and MERS-CoV were 12 and 153, respectively (19). Interestingly, for high similarity of receptor-binding domain (RBD) in Spikeprotein, various analyses reveal that SARS-CoV-2 uses angiotension-converting enzyme 2 (ACE2) as receptor, just like as SARS-CoV. Coronavirus essentially recognizes the corresponding receptor on the target cell via the $\mathrm{S}$ protein on its surface and enters into the cell, then causing the occurrence of infection. A structure model analysis shows that SARS-CoV-2 binds ACE2 with above 10 folds higher interest than SARSCoV, but higher than the threshold needed for virus infection (11). According to the general acceptance, origin of COVID-19, Figure 2 (20).

The mechanisms and effects of a well-known virus family on host cell

It has been confirmed that 2019-nCoV uses the same cell entry receptor angiotensin converting enzyme II (ACE2) as SARS-CoV (16). Besides pulmonary tissue, ACE2 is also highly expressed in digestive system, composed of esophagus, stomach, small intestine, duodenum and kidney (21). The mechanisms of infection patway of COVID-19 virus can be drawn as in below Figure 3 (22).

\section{Clinical symptoms}

The most prevalant indications at the beginning of the infection are fever $(82.1 \%)$, cough $(45.8 \%)$, fatigue $(26.3 \%)$, shortness of breath $(6.9 \%)$ and headache $(6.5 \%)$. The median incubation period was 6.7 days, the time between the beginning of the disease and consult a doctor was 4.5 days. In 


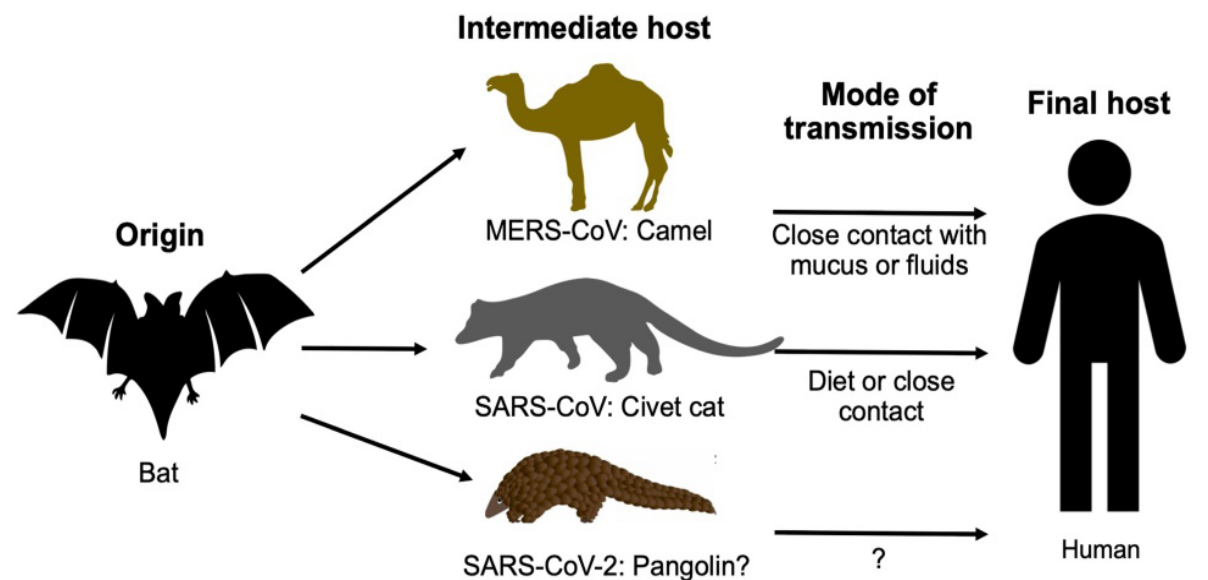

Figure 2. The origin of COVID-19, though still controversial (20).

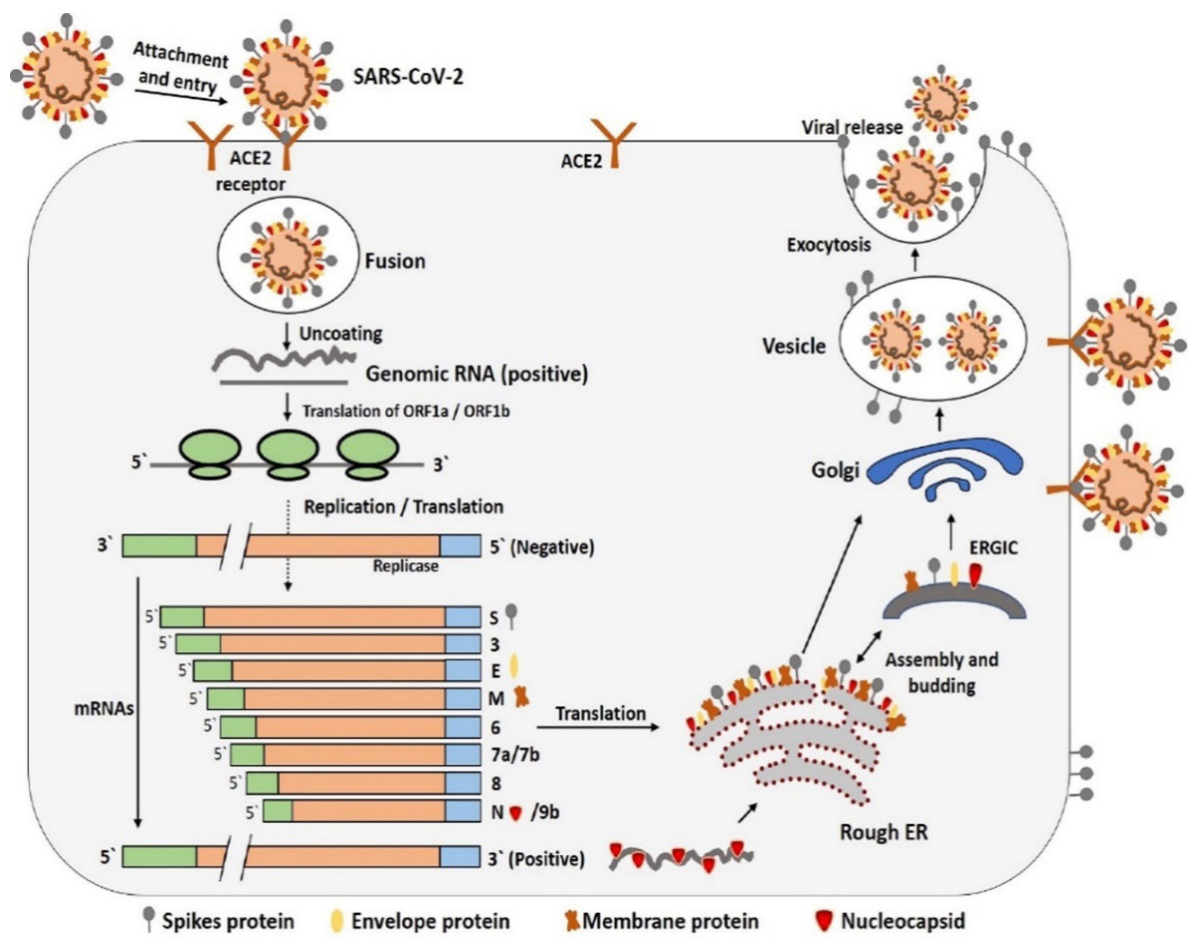

Figure 3. The entering and infection mechanism of COVID-19 to human cell (22).

the study conducted as of February $10,17.2 \%$ of the patients were discharged and $81.7 \%$ of them were hospitalized, the mortality rate of COVID-19 infection in Beijing is $0.9 \%$ (23). Results from meta-analysis, including 46.248 infected patients, showed that the most common clinical symptom was fever $(91 \pm 3.95 \%$ $\mathrm{Cl} 86-97 \%)$ followed by cough $(67 \pm 7.95 \% \mathrm{Cl} 59-76 \%)$, fatigue $(51 \pm 0.95 \% \mathrm{Cl} 34-68 \%)$ and dyspnea $(30 \pm$ $4.95 \% \mathrm{Cl} 21-40 \%$ ) (14). For 656 patients, fever (88.7\%, 95\% Cl 84.5-92.9\%), cough (57.6\%, 95\% Cl 40.8-74.4\%) 
and dyspnea $(45.6 \%, 95 \% \mathrm{Cl} 10.9-80.4 \%)$ were the most common symptoms. Among the patients, 20.3\% (95\% Cl 10.0-30.6\%) needed intensive care unit (ICU), $32.8 \%$ posed with acute respiratory distress syndrome (ARDS) (95\% Cl 13.7-51.8), 6.2\% (95\% Cl 3.1-9.3) with shock. ICU was desired for nearly $20 \%$ of polymorbid, COVID-19 infected patients and hospitalization was related with a Case Fatality Rate (CFR) of $>13 \%$ (24). General clinical symptoms whether they are changed in pandemia period like as below at Figure 4 (25).

According to WHO data, diarrhea, sore throat, headache, difficulty swallowing, joint pain, skin rashes and discoloration of the fingers and toes were also added to existing symptoms of high fever, dry cough, shortness of breath, loss of taste and smell (Figure 4)

\section{Laboratory and radiological results}

The increasing of neutrophils, Serum amyloid A (SAA), procalcitonin (PCT), C-reactive protein (CRP), cTnI, D-dimer lactate dehydrogenase (LDH) and lactate amount can be used as markers of illness progression, as well as the decrease of lymphocytes counts (26). ICU patients had higher IL2, IL7, IL10, GSCF, IP10, MCP1, MIP1A and TNF-a plasma levels compared to non-ICU patients (27). According to chest X-ray and CT, 74 (75\%) patients had bilateral pneumonia, while only 25 (25\%) patients had unilateral pneumonia and $14(14 \%)$ patients had multiple mottling and ground glass opacity (28). There was no statistically significant difference in creatinine, aspartate amino transferase (AST), alanine aminotransferase (ALT), bilirubin, CRP, creatine kinase (CK) and LDH levels between COVID-19 and non-COVID-19 groups (29). The reduction of CD3 +, CD4 + and CD8 + T lymphocyte correlated with the course of patients with COVID-19 pneumonia, especially in severe cases. T lymphocyte level can be used as an indicator of the severity and prognosis of patients with COVID-19 pneumonia (30). Serum cytokine levels of IL-2R, IL-6, IL-10, and TNF- $a$ and high LDH levels were notably higher in severe

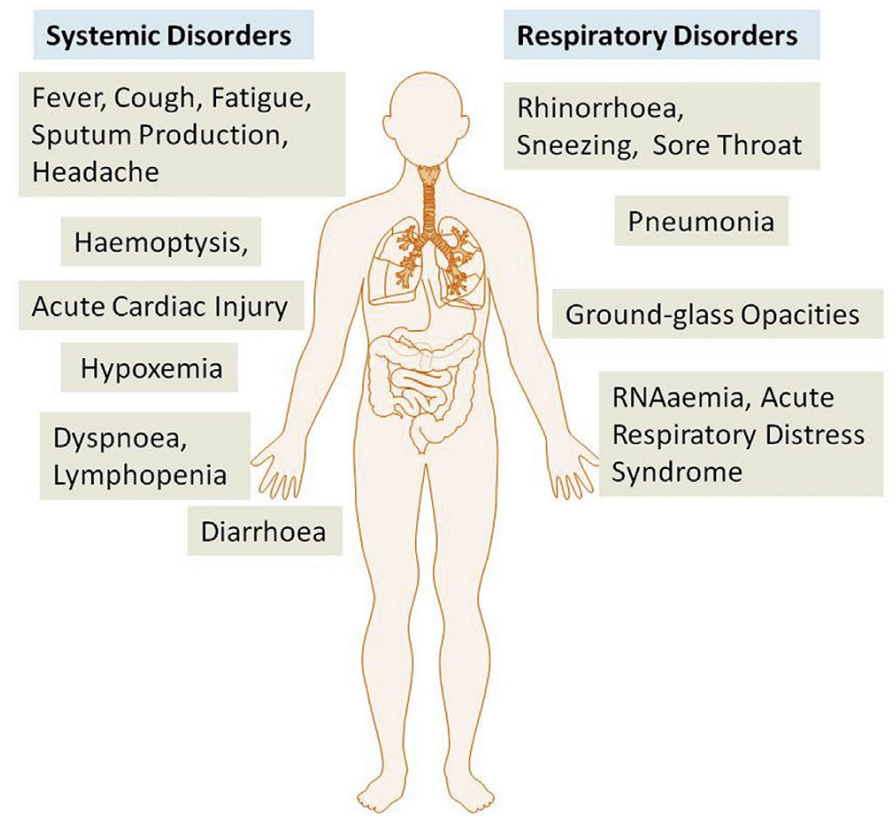

Figure 4. The general and most seen symptoms of COVID-19 (25). 
patients than those in non severe patients (31). Troponin levels were importantly increased in the week antecedent the death. 15 (13.4\%) patients have introduced marks of pulmonary hypertension (32). The most common laboratory abnormalities were high CRP (68.6\% [58.2-78.2]) and decreased lymphocyte count $(57.4 \%$ [44.8-69.5]) as well as increased LDH (51.6\% [31.4-71.6]). The most common chest CT findings were ground glass opacities $(80.0 \%$ [67.390.4]) and bilateral pneumonia (73.2\% [63.4-82.1]). ARDS was the most common complication (15.7\% [5.0-30.4]) (33). Eosinophil values were little on first hospitalization, later overall became normal before discharge. Rising of eosinophils may be an indicator of COVID-19 recovery (34).

The gold standard in routine microbiological diagnosis for SARS-CoV-2 is to demonstrate the presence of viral RNA in real-time reversetranscriptase-polymerase chain reaction (RT-PCR) in appropriate clinical samples. Although there are tests investigating the presence of antigens in clinical samples, these tests are not recommended for use in clinical diagnosis due to their low sensitivity and specificity. In the light of the available information, the samples that should be taken from the patients for the direct diagnosis of the infection with RT-PCR are respiratory samples (35).

\section{Medicines used for treatment}

Remdesivir and chloroquine have been shown to effectively inhibit SARS-CoV-2 in vitro. Therefore, other nucleoside analogs such as favipiravir, ribavirin and galidesivir are potentially clinically usable against SARS-CoV-2 (3). Arbidol combined with $\mathrm{LPV} / \mathrm{r}$ can help delay the progression of lung lesions and reduce the likelihood of respiratory and gastrointestinal transmission to reduce the viral load of COVID-19 (36). Clinically controlled studies have proven that chloroquine is effective in the treatment of patients with COVID-19. Remdesivir undergoes numerous clinical trials in several hospitals, and the final effectiveness of the drug is uncertain. Arbidol, a small indole derivative molecule, has been confirmed to block viral fusion against influenza $A$ and $B$ viruses and hepatitis $C$ viruses and have an antiviral effect on SARS-CoV in the cell assay, so it may be a choice for COVID-19 therapy (37). Currently, there is no vaccine or antiviral therapy for human and animal coronavirus. General strategies include bed rest and antiviral therapy, antibiotic administration, immunomodulatory therapy, organ function support, respiratory support, bronchoalveolar lavage (BAL), blood purification and extracorporeal membrane oxygenation (ECMO) (10).

Whole patients were cured in isolated condition. 75 (76\%) patients had antiviral treatment, including oseltamivir (75 mg every $12 \mathrm{~h}$, orally), ganciclovir $(0.25$ g every $12 \mathrm{~h}$, intravenously), and lopinavir and ritonavir tablets (500 $\mathrm{mg}$ twice daily, orally). The length of antiviral therapy was 3-14 days (median 3 days). When secondary bacterial infection happened, the antibiotics utilized were cephalosporins, quinolones, carbapenems, tigecycline against methicillin resistant Staphylococcus aureus, linezolid, and antifungal drugs. The length of antibiotic therapy was 3-17 days (median 5 days). 19 (\%19) patients were treated with methylpred nisolone sodium succinate, methylprednisolone, and dexamethasone for 3-15 days (median 5) (28). Therapy of hydroxychloroquine is remarkably correlated with reduced or lost viral load in COVID-19 patients, and its impact is enhanced by azithromycin (38). Chloroquine is one of the most greatly used anti-malaria drugs widespread, but has also been examined as a potential broad-spectrum anti-viral drug. Chloroquine also seems to intervene with terminal glycosylation of ACE2 and therefore can eliminate virus-receptor binding and infection (39).

In severe COVID-19, the use of corticosteroids early (immediately after hospitalization or within the first three days after hospitalization) can control disease progression or prevent further deterioration of the disease (40). The data suggest that arbidol monotherapy may be superior to lopinavir/ritonavir 
in the treatment of COVID-19 (41). Treatment of cytokine storm has become an important part of saving serious patients. Tocilizumab is an IL-6R blocker that can effectively block the IL-6 signal transduction pathway. Therefore, tocilizumab is likely to be an effective drug for patients with severe COVID-19 (42). Some researchers in Turkey also studied on Dornase alfa which is used to reduce the number of lung infections and to improve lung function in patients with cystic fibrosis, to use against COVID-19. Moreover, the sale of the drug, which is produced by a local pharmaceutical company for use in the treatment of COVID-19, has been granted nowadays. The search for the treatment with existing drugs will continue until the specific drugs are developed against COVID-19.

The course of outbreak: now and future

Treatment of cytokine storm has become an important part of saving serious patients. Tocilizumab is an IL-6R blocker that can effectively block the IL-6 signal transduction pathway. Therefore, tocilizumab is likely to be an effective drug for patients with severe COVID-19 (43).

Hydroxychloroquine sulfate and chloroquine phosphate are antimalarial drugs used in malaria treatment. Hydroxychloroquine inhibits Plazmodium malaria cell to not entering human cell and prevent high fever. If the COVID-19 virus is prevented from entering the cell, it can be ensured membrane stability. Certanly, every drug has side effects. With the proposal of Paracelsus, it is the dose that distinguishes the drug from poison. The new coronavirus 2019 of the SARS family is named by the world health organization as COVID-19. Since it is classified in a known virus family, at the beginning, it is normal to try the drugs used for SARS and MERS. Although there is no general belief that they are beneficial and show improvement, it is a fact that a treatment protocol will be established with the drugs available. A medication or a prophylactic vaccine can be developed for the treatment of COVID-19, the mechanism of action of which is known. It is stated that drug synthesis will take a long time from the chemical synthesis phase, including studies in cell culture and experimental animals. Moreover, even if the phase I, phase II and phase III studies are accelerated in volunteers and patients, it will not be possible in less than 1 year. Although there is no specific drug in the treatment protocol that has undergone sufficient trials and can be used against COVID-19, neither patients nor doctors are waiting. Taking advantage of the similarity of existing drugs, most of the drugs available are used in the treatment of some patients. If these drugs are not used with proper dosage, appropriate duration and suitable patient, it causes a condition that metabolism cannot handle and the patient is lost. It is expected that China will be experienced since the use of drugs within the trial and error first started in China. We expect that trials on drug use and disease treatment will lead to the development and acceleration of evidence-based medicine worldwide. From the scientific committee and the Ministry of Health's statements, doctors are using what drugs and methods of treatment are used based on the evidence. Every day, new studies on transmission routes and new findings about how long the virus remains in sick people are emerging. As stated in the studies, while the virus has been kept alive in the human body for the longest 37 days, in recent studies it is possible to remain alive in the human body for 49 days. It is stated that everyone should wear a mask in public spaces, whether they are sick or not. Everyone can be a potential carrier because of the high transmission of the virus and no symptoms at all.

\section{CONCLUSION}

As in one study, higher post-oxygen supplement $\mathrm{SpO} 2$ levels were associated with reduced mortality regardless of age and gender (44). A study in the city of Indonesia, Jakarta, found that weather is an important factor in determining the COVID-19 
incidence rate. A significant correlation is shown between the temperature averages and COVID-19 pandemic (45). According to empirical outputs, the relationship between temperature and COVID-19 was mostly positive for Hubei, Hunan and Anhui, while was mostly negative for Zhejiang and Shandong provinces (46). Almost every day a new drug, oxygen therapy, prone position, vitamins and similar chemicals were recommended for therapeutic or prophylactic purposes. Strengthening the immune system is important, but the fact that the immune system is strong enough may be a more accurate approach. It is also difficult for the organism to be negatively affected by its own immune system by exposure to cytokine bombardment. Neither a very strong immune system nor a weak, self-protecting immune system is sufficient.

Vitamin $D$ is found in oily fish (eg herring, salmon and sardines), as well as cold liver oil. In addition to vitamin D from foods, it is synthesized in the skin with sunlight. Vitamin $D$ deficiency has been associated with an increased risk of common cancers, autoimmune diseases, hypertension and infection recovery. Vitamin C plays a role in neutralizing the free radicals in the body by working with vitamin $\mathrm{E}$ as an antioxidant to wound healing, bone and tooth growth, strengthening blood vessels and walls, and increasing absorption and use of iron (47-50). The reasonable aspect of the doctors' Vit D3 recommendation is that people are not able to consume enough fatty fish and similar products, and because they do not go out, their exposure to the sun and the ultraviolet rays they receive on the skin are very low. Another recommended vitamin is vitamin C. It is that vitamin C, which is given in abundance intravenously, protects against this disease. Another drug-like substance is the collection of immune plasma from patients who have undergone COVID-19 and who have recovered completely using apheresis technique and used in patients. Intubation devices should be produced, but qualified personnel who will use these machines are also needed. In the world, it is ensured that intensive care units are used effectively due to the fact that patients without respiratory distress do not go to the hospital and stay at home. Initially, this was desirable in Turkey. With the devoted work of healthcare workers and the healthcare system not collapsing, it has caused everyone who had symptoms of this disease called to hospitals for treatment. As a result of the success of the health system in Turkey, the total hospital bed occupancy rate did not exceed $30-32 \%$, the intensive care bed occupancy also did not exceed rates of 60 $62 \%$. The drugs used in our country and the drugs that are said to be beneficial are antimalaria medicines known as hydroxychloroquine, favipiravir, which is an antiviral drug, and an antibacterial, azithromycin. It is also used in supportive treatments. Treatment success increases with the use of these drugs within the scope of rational drug use principles, appropriate dose, appropriate patient, appropriate duration and the right way. Furthermore, controlled experiments must be carried out to determine the effects of the drugs used in treatment. 


\section{KAYNAKLAR}

1. Rothan HA, Byrareddy SN. The epidemiology and pathogenesis of coronavirus disease (COVID-19) outbreak. J Autoimmun, 2020; 109: 102433.

2. Zhou F, Yu T, Du R, Fan G, Liu Y, Liu Z, et al. Clinical course and risk factors for mortality of adult inpatients with COVID-19 in Wuhan, China: a retrospective cohort study. Lancet, 2020; 395(10229):1054-62.

3. Li X, Geng M, Peng Y, Meng L, Lu S. Molecular immune pathogenesis and diagnosis of COVID-19. J Pharm Anal, 2020;10 (2): 102-8.

4. Zhao S, Lin Q, Ran J, Musa SS, Yang G, Wang $\mathrm{W}$, et al. Preliminary estimation of the basic reproduction number of novel coronavirus (2019-nCoV) in China, from 2019 to 2020: a data-driven analysis in the early phase of the outbreak. Int J Infect Dis, 2020; 92: 214-7.

5. Yang W, Cao Q, Qin L, Wang X, Cheng Z, Pan $A$, et al. Clinical characteristics and imaging manifestations of the 2019 novel coronavirus disease (COVID-19): a multi-center study in Wenzhou city, Zhejiang, China. J Infect, 2020; 80(4): 388-93.

6. Ho LTF, Chan KKH, Chung VCH, Leung TH. Highlights of traditional Chinese medicine frontline expert advice in the China national guideline for COVID-19. Eur J Integr Med, 2020; 36: 101116.

7. Liu Y, Gayle AA, Wilder-Smith A, Rocklov J. The reproductive number of COVID-19 is higher compared to SARS coronavirüs. J Travel Med, 2020; 27(2): taaa021.

8. Desjardins MR, Hohl A, Delmelle EM. Rapid surveillance of COVID-19 in the United States using a prospective space-time scan statistic: detecting and evaluating emerging clusters. Appl Geogr, 2020; 118 (102202):1-7.

9. Thomas P, Baldwin C, Bissett B, Boden I, Gosselink R, Granger CL, et al. Physiotherapy management for COVID-19 in the acute hospital setting: clinical practice recommendations. J Physiother, 2020, 66 (2): 73-82.
10. Wu D, Wu T, Liu Q, Yang Z. The SARS-CoV-2 outbreak: what we know. Int J Infect Dis, 2020; 94: 44-8.

11. Wang $L$, Wang $Y$, Ye $D$, Liu $Q$. A review of the 2019 Novel Coronavirus (COVID-19) based on current evidence. Int J Antimicrob Agents, 2020; 55(6):105948.

12. Fanzca AB, Loh $M H$, Tan $C H$, SU LL, Young BE, Lye DC, et al. Care of the pregnant woman with covid-19 in labor and delivery: anesthesia, emergency cesarean delivery, differential diagnosis in the acutely ill parturient, care of the newborn, and protection of the healthcare personnel. Am J Obstet Gynecol, 2020; 223 (1): 66-74.

13. Gautret $P$, Lagier JC, Parola P, Hoang VT, Meddeb $\mathrm{L}$, Sevestre J, et al. Clinical and microbiological effect of a combination of hydroxychloroquine and azithromycin in 80 COVID-19 patients with at least a six-day follow up: A pilot observational study. Travel Med Infect Di, 2020; 34: 101663.

14. Liang K. Mathematical model of infection kinetics and its analysis for COVID-19, SARS and MERS. Infect Genet Evol, 2020; 82:104306.

15. Yang J, Zheng Y, Gou X, Pu K, Chen Z, Guo Q, et al. Prevalence of comorbidities in the novel Wuhan coronavirus (COVID-19) infection: a systematic review and meta-analysis. Int J Infect Dis, 2020. 94: 91-5.

16. Verity R, Okell LC, Dorigatti I, Winskill P, Whittaker C, Imai N, et al. Estimates of the severity of coronavirus disease 2019 : a modelbased analysis. Lancet Infect Dis, 2020; 20(6): 669-77.

17. Daily Table of COVID-19 For Turkey. https:// covid19.saglik.gov.tr. (Accessed Date: May 22, 2020).

18. Zhou P, Yang XL, Wang XG, Hu B, Zhang L, Zhang $W$, et al. A pneumonia outbreak associated with a new coronavirus of probable bat origin. Nature, 2020; 579: 270-3. 
19. Kandeel M, Al-Nazawi M. Virtual screening and repurposing of FDA approved drugs against COVID-19 main protease. Life Sci, 2020; 15:117627.

20. Yi Y, Lagniton PNP, Ye S, Li E, Xu RH. Int J Biol Sci, COVID-19: what has been learned and to be learned about the novel coronavirus disease. 2020;16(10):1753-66.

21. Zhang H, Kang Z, Gong H, Xu D, Wang J, Li Z, et al. The digestive system is a potential route of 2019-nCov infection: a bioinformatics analysis based on single-cell transcriptomes.BioRxiv, 2020; 2020.01.30.927806.

22. Shereen MA, Khan S, Kazmi A, Bashir N, Siddique R. COVID-19 infection: Origin, transmission, and characteristics of human coronaviruses. J Adv Res, 2020; 24:91-8.

23. Tian S, Hu N, Lou J, Chen K, Kang Z, Ziang Z, et al. Characteristics of COVID-19 infection in Beijing. J Infect, 2020; 80(4): 401-6.

24. Rodriguez-Morales AJ, Cardona-Ospina JA, Gutiérrez-Ocampo E, Villamizar-Peña R, Holguin-Rivera Y, Escalera-Antezana JP, et al. Clinical, laboratory and imaging features of COVID-19: a systematic review and metaanalysis. Travel Med Infect Dis, 2020; 34: 101623.

25. Coronavirus Disease (COVID-19) events as they happen. World Health Organization. https:// www. who.int/emergencies/diseases/novelcoronavirus-2019/events-as-they-happen, (Accessed Date: April 30, 2020).

26. Li X, Wang L, Yan S, Yang F, Xiang L, Zhu J, et al. Clinical characteristics of 25 death cases with COVID-19: a retrospective review of medical records in a single medical center, Wuhan, China. Int J Infect Dis, 2020; 94: 128-32.

27. Huang C, Wang Y, Li X, Ren L, Zhaou J, Hu Y, et al. Clinical features of patients infected with 2019 novel coronavirus in Wuhan, China. Lancet, 2020; 395(10223): 497-506.

28. Chen N, Zhou M, Dong X, Jieming Q, Gong F, Han $Y$, et al. Epidemiological and clinical characteristics of 99 cases of 2019 novel coronavirus pneumonia in Wuhan, China: a descriptive study. Lancet, 2020; 395(10223):50713.
29. Hsih WH, Cheng MY, Ho MW, Chou CH, Lin PC, Chi CY, et al. Featuring COVID-19 cases via screening symptomatic patients with epidemiologic link during flu season in a medical center of central Taiwan. J Microbiol Immunol Infect, 2020; 53(3): 459-66.

30. He R, Lu Z, Zhang L, Fan T, Xiong R, Shen X, et al. The clinical course and its correlated immune status in COVID-19 pneumonia. J Clin Virol, 2020; 127: 104361.

31. Li X, Xu S, Yu M, Wang K, Tao Y, Zhou Y, et al. Risk factors for severity and mortality in adult COVID-19 in Wuhan. J Allergy Clin Immunol, 2020 146(1): 110-8.

32. DengQ, Hu B, Zhang $\mathrm{Y}$, Wang $\mathrm{H}$, Zhou X, Wei Hu, et al. Suspected myocardial injury in patients with COVID-19: evidence from front-line clinical observation in Wuhan, China. Int J Cardiol, 2020; 311: 116-21.

33. Fu L, Wang B, Yuan T, Chen X, Ao Y, Fitzpaatric $T$, et al. Clinical characteristics of coronavirus disease 2019 (COVID-19) in China: a systematic review and meta-analysis. J Infect, 2020; 80(6): 656-65.

34. Liu F, Xu A, Zhang Y, Xuan W, Yan T, Pan K, et al. Patients of COVID-19 may benefit from sustained lopinavir-combined regimen and the increase of eosinophil may predict the outcome of COVID-19 progression. Int J Infect Dis, 2020; 95:183-91.

35. Wong JEL, Leo YS, Tan CC. COVID-19 in Singapore-current experience: critical global issues that require attention and action. JAMA, 2020; online ahead of print.

36. Deng L, Li C, Zeng Q, Liu X, Li X, Zhang H, et al. Arbidol combined with $\mathrm{LPV} / \mathrm{r}$ versus $\mathrm{LPV} / \mathrm{r}$ alone against corona virus disease 2019:a retrospective cohort study. J Infect, 2020; 81(1): e1-e5.

37. Wang L-S, Wang Y-R, Ye D-W, Liu Q-Q. A review of the 2019 novel coronavirus (COVID-19) based on current evidence. Int J Antimicrob Agents, 2020: 55(6): 105948.

38. Gautret P, Lagier JC, Parola P, Hoang VT, Meddeb L, Mailhe $M$, et al. Hydroxychloroquine and azithromycin as a treatment of COVID-19: results of an open-label non-randomized clinical trial. Int J Antimicrob Agents, 2020; 20: 105949. 
39. Wu C-I, Postema PG, Arbelo E, Behr ER, Bezzina CR, Napolitano C, et al. SARS-CoV-2, COVID-19 and inherited arrhythmia syndromes. Hear Rhythm. 2020, 31; S1547-5271(20)30285-X.

40. Zheng C, Wang J, Guo H, Lu Z, Ma Y, Zhu Y, et al. Risk-adapted treatment strategy for COVID-19 patients. Int J Infect Dis. 2020, 94:74-77.

41. Zhu Z, Lu Z, Xu T, Chen C, Yang G, Zha T, et al. Arbidol monotherapy is superior to lopinavir/ ritonavir in treating COVID-19. J Infect, 2020; 81(1):e21-e23.

42. Zhang C, Wu Z, Li J-W, Zhao H, Wang G-Q. The cytokine release syndrome (CRS) of severe COVID-19 and interleukin-6 receptor (IL-6R) antagonist tocilizumab may be the key to reduce the mortality. Int $\mathrm{J}$ Antimicrob Agents, 2020; 55(5):105954.

43. Amrane S, Tissot-Dupont H, Doudier B, Eldin C, Hocquart M, Mailhe M, et al. Rapid viral diagnosis and ambulatory management of suspected COVID-19 cases presenting at the infectious diseases referral hospital in Marseille, France, - January 31st to March 1st, 2020: a respiratory virus snapshot. Travel Med Infect Dis, 2020; 20;101632.

44. Xie J, Covassin N, Fan Z, Singh P, Gao W, Li $G$, et al. Association between hypoxemia and mortality in patients with COVID-19. Mayo Clin Proc. 2020, 95(6): 1138-47.

45. Tosepu R, Gunawan J, Effendy DS, Ahmad LOAI, Lestari H, Bahar H. et al. Correlation between weather and Covid-19 pandemic in Jakarta, Indonesia. Sci Total Environ, 2020; 725: 138436.

46. Shahzad F, Shahzad U, Fareed Z, Iqbal N. Hashmi SH, Ahmad F. Asymmetric nexus between temperature and COVID-19 in the top ten affected provinces of China: a current application of quantile- on-quantile approach. Sci Total Environ, 2020; 736:139115.
47. Karageçili H. Vitaminler. In: Pașaoğlu H, ed. Temel - Klinik Tıbbi Laboratuvar. 1. Baskı. Ankara. Pelikan Tıp Teknik Yayıncılık - Akademik Kitaplar, 2018: 81-8.

48. Bozalioğlu S, Kılıç N, Yıldırım Z, Baștürk B, Kurukahvecioğlu $O$. The relationship between HLA-G levels and oxidative stress parameters in patients with breast cancer. Turk J Med Sci, 2013; 43(6): 870-7.

49. Yıldırım Z, Uçgun NI, Yıldırım F. The role of oxidative stress and antioxidants in the pathogenesis of age-related macular degeneration. Clinics (Sao Paulo), 2011; 66(5): 743-6.

50. Uçgun NI, Yıldırım Z, Abbasoğlu ÖE, Özel Ü, Fikret ZC, Bilgihan A, et al. Senil katarakt ilerlemesi ve askorbik asit. MN Oftalmol, 2005; 12: $10-2$.

51. Biswal M, Rudramurthy SM, Jain N Shamanth AS, Sharma D, Jain K, et al. Controlling a possible outbreak of Candida auris infection: lessons learnt from multiple interventions. J Hosp Infect, 2017; 97: 363-70.

52. Schelenz S, Hagen F, Rhodes JL Abdolrasouli A, Chowdhary A, Hall A, et al. First hospital outbreak of the globally emerging Candida auris in a European hospital. Antimicrob Resist Infect Control, 2016; 5: 35.

53. Anonymous. http://www.promedmail.org/ post/20180425.5767936, (Erișim Tarihi: 15.05. 2019). 